\title{
LIMITS OF ECOLOGICAL LOAD IN PUBLIC PARKS - ON THE EXAMPLE OF VÁROSLIGET
}

\author{
SZILÁGYI, K. ${ }^{1}{ }^{*}$ - ZELENÁK, F. ${ }^{1}$ - KANCZLERNÉ VERÉB, M. ${ }^{1}-$ GERZSON, L. ${ }^{1}-$ \\ CZEGLÉDI. CS. ${ }^{1}-$ BALOGH, P.I. ${ }^{1}$ \\ ${ }^{I}$ Corvinus University of Budapest, Faculty of Landscape Architecture, Department for Garden \\ and Open Space Design \\ 1118 Budapest, Villányi út 27-43. \\ (phone: +36-1-482-6289; fax: +36-1-482-6291) \\ *Corresponding author \\ e-mail: kinga.szilagyi@uni-corvinus.hu \\ (Received $28^{\text {th }}$ Jul 2014; accepted $2^{\text {nd }}$ Sep 2014)
}

\begin{abstract}
The public city parks have gone through several changes during their culture of centuries, together with the density, environmental quality and society of the cities they were established in. The metropolises developed rapidly after the industrial revolution of the $18-19^{\text {th }}$ centuries, and the demand for public spaces, acceptable air quality and healthier living conditions became urgent. In addition to the technical solutions, the appearance of the public parks brought remission to the public sanitation problems. Public parks are still the places for daily recreation. On the other hand, they are special urban ecosystems, with mostly installed, partly spontaneous vegetation. The parks surrounded by densely builtin neighbourhoods are subjected to multiple environmental impacts: beyond the recreational traffic, the modified climatic conditions and the load of the urban environment show significant impact as well. On the example of the City Park of Budapest (hereafter Városliget) several impacts on a public park and the changes in the ecosystem can be observed. The new Museum Quarter (or so-called Liget Budapest) Project adds a special actuality to the research, as it brings several new cultural-touristic installations and an increasing area of built-in territories to the historical green. The constructions can bring sweeping changes, endangering the ecological balance of the park.
\end{abstract}

Keywords: people - environment relation, environmental impact, public park, Városliget, park user survey

\section{Introduction}

From the end of the $17^{\text {th }}$ century the royal and court gardens, game preserves became open for the public one after the other, and by the beginning the $19^{\text {th }}$ century, the first parks and gardens purposely built for the citizens were open (Szilágyi and Veréb, 2014). According to the rapid civilization, the industrial revolution and the failing environmental quality of the progressively developing metropolises, an increasingly urgent need for open spaces, healthy air, better and healthier urban habitats and living conditions, and the control of epidemics arose. In addition to the technical solutions (sewer system, clean potable water), the appearence of public parks giving sunlight and good air brought remission to the public sanitation problems. The social-sanitary function of the city greens, although with different content and scale, is still existing (Chadwick, 1966; Toorn, 2014).

City greens are still serving daily recreational purposes, welcoming a large number of visitors day by day. These special urban ecosystems are built up partly from intentionally installed vegetation, and partly from the local, conditioning natural flora. The parks surrounded by densly built-in neighborhoods are subjected to multiple environmental impact: beyond the recreational traffic, the modified climatic conditions, 
soil and air pollution, the modification of groundwater flow and the edifices of cultural and sport facilities show significant impact as well. The healthy vegetation and the quality of urban greens can be assured only by the reduction and continous compensation of impacts.

The City Park of Budapest (Városliget) has been serving the citizens for more than 200 years. The park was once established by the edge of the city of Pest, marking out a new way of urban development for the $18^{\text {th }}$ century. By the beginning of the 20th century the city limits were closing in to the area. During its history Városliget gave place to several events requireing partial, temporary built-up areas. Its territory hosted a grand variety of requisitions, but its recreational and urban ecological role always remained significant. The relief and clearing of the park was a target of several urban development and green space programs. The establishment of Népliget in 1896, the new city park for the 'plebeian class' was carried out for the open space entartainment and leisure of lower class families (Csepely-Knorr, 2011). The pleasure grounds and entertainment facilities of Városliget was moved to Népliget in 1911, to protect the park and reduce the impacts. The natural beauties of Városliget were compareable only to the ones of Margitsziget that time, it's rich and diverse vegetation is still the most important value.

During the medieval ages Városliget was a rich royal game preserve, but later in the Ottoman times it became a marshy, sandy wasteland. By the end of the $17^{\text {th }}$ century, in accordance to the decree of Leopold the $1^{\text {st }}$, the area became the property of the Municipality of Pest. It was mostly used for grazing until intensive forestation was declared by Joseph the $2^{\text {nd }}$. As the process of forestation went on, more and more citizens visited the area for a walk, or even for short excursions. The planned transformation of the forest to a more preferable recreational area was started by Archbishop Joseph Batthyány, first with the drainage of the swamps, construction of roads and installment of lines of trees. The Royal Beautifying Commission (Királyi Szépítő Bizottság) initiated the formation of Városliget into a public park in 1809 (Schams, 1821). The garden design plan was layed out by Heinrich Nebbien between 1813-19. It was evident to Nebbien that to make a city liveable, the residents should be able to enjoy Nature, the green representing physical and mental refreshment. It should be an integrated part of the city, within reach, realized in a sound, experiental and maintainable quality.

Although Nebbiens creation of garden art could only be partially implemeted, some segments and elements of the park, but mostly its spirit faithfully represented the specific, romatic vision of nature of the beginning of the $19^{\text {th }}$ century. In the end of the $19^{\text {th }}$ century a large part of the park was leveraged as the expositional area of the millenium celebrations, while other parts were annexed to different institutional developments. Despite of the built-in territories and the changes of usage, Városliget still provides the experience of nature (Szilágyi and Veréb, 2014). The most important value of the park is the mature vegetation deriving from the plantings of the $19^{\text {th }}$ century, as the plantations began with the 180 plane trees offered by Palatine Joseph. These trees adapted very well to the local endowments of high underwater levels, no wonder that the plane trees are still the oldest and most magnificent in the park. The proposed developments risk the health and survival of the valuable, forest-like vegetation, the foremost ecological and recreational virtue of Városliget.

After the $19^{\text {th }}$ century upswing of the public parks, urban development and the social, but mostly the economic pressure often lead to the temporary or permanent building up 
of open spaces, and not only the decline of the romantic vision of nature, but the reduction of maintenance costs strengthened the process. From the second half of the century exhibition shows became more and more popular, which led to a more intensive usage of public parks. The Grosser Garten in Dresden gave place to exhibitions between the world wars, but fortunately only for temporary ones (Krihning, 2013). The Városliget was a popular location for exhibitions and markets, and these space reservations brought decay for the valuable vegetation.

Research of the park usage and ecological state of the City Park is popular since the 1980s. Academic dissertations and studies showed the characteristics of the recreational uses of the park, including the events regularly held in Városliget, attracting large amount of visitors year by year (Nagy, 1997; Capital Research 2007; Szilágyi, 2006.).

Among researches of urban ecology and urban green, the analysis of the phenomenon of urban heat islands occupies a prominent place (Bakay, 2012). The extensive surfaces of large city parks are important areas in the production of cool air, which are refreshing islands in the traditional, densely built-in city districts (Oláh, 2012; Choi et al., 2012). However, the energy absorption of the artificial urban surfaces and the output of excess energy produced by the functioning city significantly encumber the green areas. This effect is well shown in the poor aptitude of the puffer habitats.

The park use of Városliget was brought back to front in 2013 in connection with the Museum Quarter Project. The Hungarian Parliament adopted the law CCXLII in 2013 about the restoration of Városliget. The motif of the investment is the construction of 5 new museum buildings within the boundary of the park, in conjunction with the refurbishment of the infrastructure and the green areas. The first phase of the design competition for the buildings is currently undergoing, while the reconstruction plan of the park is still to follow, unfortunately. According to the will of the government, the project will be finished by 2018 .

\section{Materials and Methods}

Being the park exposed to most of the impacts in the capital of Hungary, Városliget is analysed as a model area during the series of tests. The different types of ecological loads affecting the island-like green areas of the urban fabric are shown, along with the effects of social-recreational usage and the effects of urban local climates on the vegetation. The loads will be compared against the regional sensitivity, defined by the vegetation and coverage of separated areas. In case of urban greens, a specific aspect of inquiry is the installation of edifices enriching the recreational functions. The mass of these edifices is an artificial element in the park, forming isolated heat islands as various factors of environmental load.

In the series of environmental - ecological analyses we use professional literature analysis and data of environmental surveys to highlight the ecological changes in large scale that happened in the ecosystem of Városliget on various loads. The changes of the park ecosystem during the past two centuries the most endangered vegetation levels are the valuable, old tree stock and the grass surface. The evaluation in these aspects is based on the detailed site survey. Besides these comparative methods original research resources also have been integrated. The recreational load of the urban park could be analysed by the evaluation of a site survey of Városliget made in October 2013 and May 2014. This site survey focused on the recreation activity at Városliget, and gave detailed data about the number of park visitors on 
weekdays and in the weekend, taking into account the type of recreation as well. Besides measuring the recreational load a representative questionnaire of more than 1000 was also made to highlight the human ecological aspects of park use. Respondents' narratives were analized by qualitative methods.

\section{Results and Discussion}

\section{The environmental-ecological impacts affecting Városliget as an urban green}

The environmental-ecological impacts have been analysed on large and on local scale. The large scale evaluation covers the aspects of urban development, the change of urban climate. In case of an urban park the functional changes, parallel with the development of recreational use forms and intensity play a crucial role in defining the environmant loads affecting the park as an ecosystem.

\section{Urban heat islands - connections of the park and the urban environment}

The phenomenon of heat islands occuring in urban areas is a typical trait of our age. Green surfaces can moderate this effect, but the excessive built-in and paved areas increasingly reduce their ability to establish local microclimates. The mass of the total urban heat island has an additional negative impact on the vegetation.

The difference in surface temperatures can be analysed using high resolution satellite images. The calculation of surface temperatures based on the recordings of the Landsat TM5 satellite on the $1^{\text {st }}$ of August 2005 show a temperature between $25-35^{\circ} \mathrm{C}$ for the green surfaces of Városliget, while the built-in and paved areas (Museum of Fine Arts, Art Gallery, parking lots of Dózsa György út, Széchenyi Thermal Bath, Petőfi Concert Hall) have a remarkably higher temperature of $36-39^{\circ} \mathrm{C}$ (Gábor and Jombach, 2008; Gábor and Jombach, 2009). Surface temperature is related to the biologically active areas: where the surfice is higly covered or an open water surfice can be found, the values are low.The coverage of Városliget is 60-100\% (except for the built-up areas and the lake). The coverage of the great meadow in front of Petöfi Hall and of the Állatkert boulevard is lower (40-60\%). The maximum coverage can be found by Paál László út and Városligeti boulevard, around the Rondo an in the areas south of Zichy Mihály út.

The analysis covering the total Budapest area showed that the highest surface temperatures are found in economical and commercial areas, metropolitan residential areas and road and railway junctions. The highways and densely built-up residential areas surrounding Városliget produce high surface temperatures. At the same time, the high surface temperature of the buildings, edifices and paved areas within the boundaries (Petőfi Concert Hall, Art Gallery, Museum of Fine Arts, Heroes square and Ötvenhatosok tere) of the park (or in the bordering territories) is radiated to the environment, forming a wide puffer zone.

The appearence of new buildings in the park would bring further increase in temperature. Putting together the present heat island map (Fig. 1) and future building plan (Fig. 2) of the new Quarter we visualized the change on the surface temperature. The predicted temperatures of the new buildings are based on the current roof surface temperature of the Mücsarnok (Kunsthalle) because of its volume and size. We illustrated with this temperature values the area of the future buildings. The monumental installments of the planned Museum Quarter would increase the size of inner heat island (at the place and surroundings of Petoffi Concert Hall), while the 
three new buildings planned in Ötvenhatosok tere would increase the heat impact of the puffer zones (Fig. 3.).

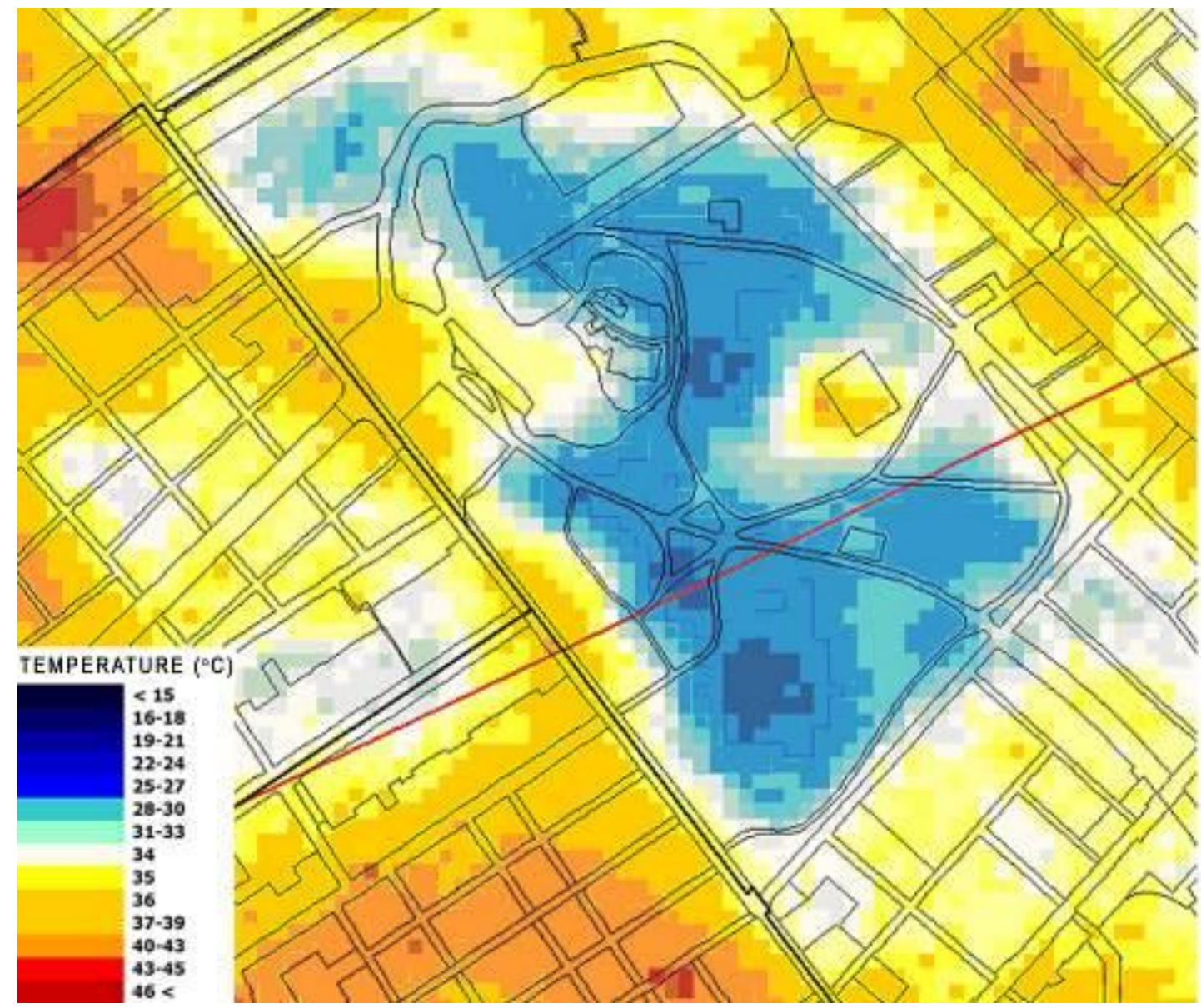

Figure 1. Calculated surface temperatures based on the recordings of Landsat (Gábor and Jombach, 2008.)

The heat island effect can be reduced by the installment of green roofs on the top of the planned buildings (VÉSZ, 2014). The measurements based on satellite images give a surface temperature of $30,5-32,5^{\circ} \mathrm{C}$ on green roofs, while a lot higher $35-39^{\circ} \mathrm{C}$ is calculated for other types of roofs. This difference cannot be observed on the ground level if the building height is large, and the planned sill height of the museums is $25 \mathrm{~m}$. According to the excessive paved areas and large building heights, a significant increase of ground level temperatures is forecasted, which will be radiated to park and its vegetation. Knowing the possible effects of global warming and aridity, the constructions would mean a serious challenge for the vegetation of Városliget, highlighting that the building-up of city parks must be restricted. 


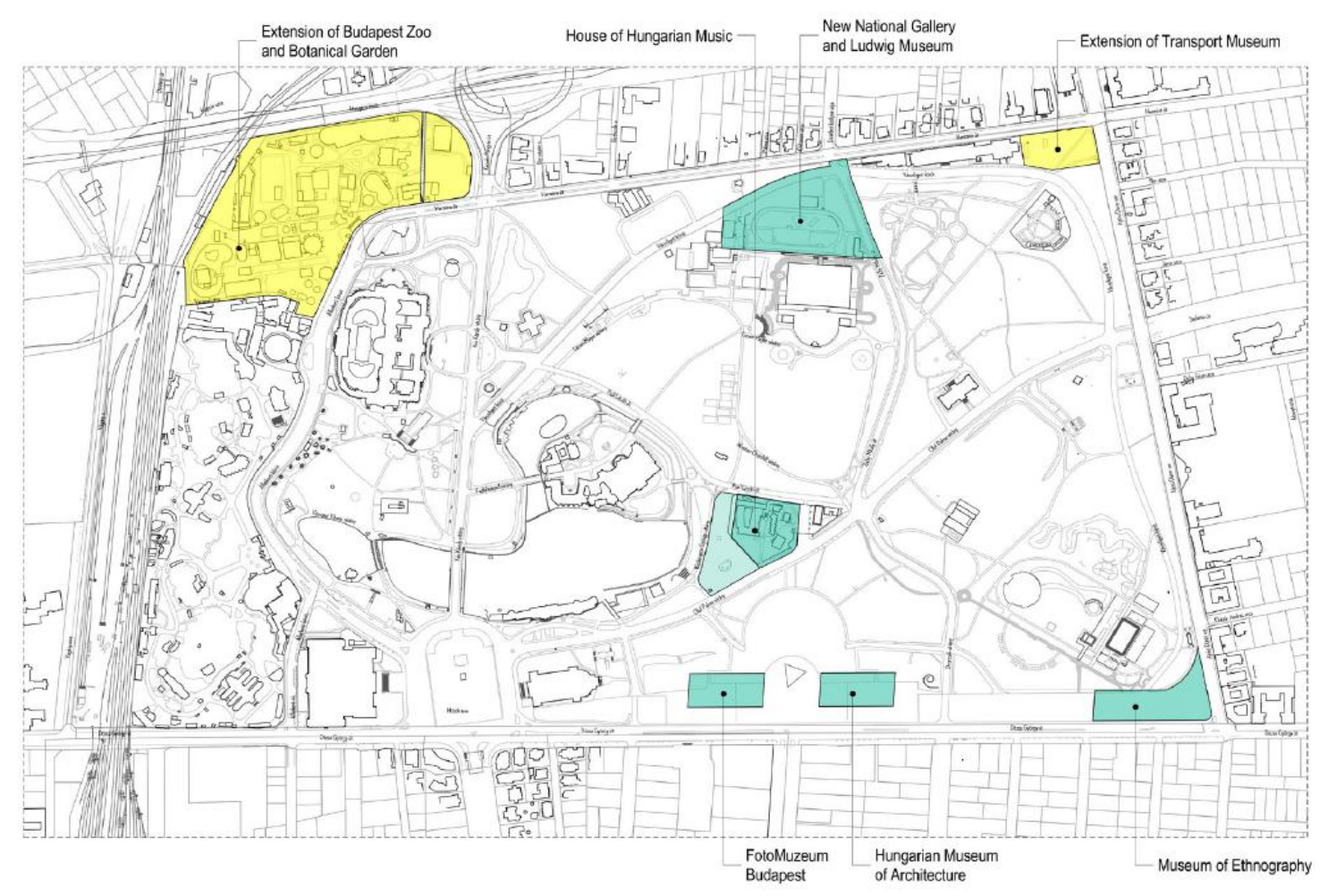

Figure 2. Planned locations of the new buildings in the Városliget

(Liget Budapest Competition Programme, 2014.)

\section{Air pollution}

According to official traffic counts, during the peak hours Kós Károly promenade is fully loaded at its full lenght because of more than $40 \%$ of the traffic of the indroductory section of the M3 motorway reaches the city center (and the P+R parkings located within the Hungária boulevard) through Városliget. So, in terms of air quality, the load of air pollution of traffic extraction is the heaviest. Concentration of nitrogen dioxide is the most critical $(42.65 \mu \mathrm{g} / \mathrm{m} 3$, while the sanitary treshold according to the $4 / 2011$ (I. 14.) VM regulation is $40 \mu \mathrm{g} / \mathrm{m} 3$ ), but the concentration of suspended articles (Pm 10) $(43.5 \mu \mathrm{g} / \mathrm{m} 3$, the sanitary treshold is $40 \mu \mathrm{g} / \mathrm{m} 3)$ is high as well.

The offload of transit traffic from Kós Károly promenade is included in the plans of the Museum Quarter, which is a pressing problem regarding the usage and protection of Városliget. Despite of the plans, the road development necessary for the offload is not mentioned in the Városliget Construction Regulation. The M3 junction with the overpass system and its feeder routes affect a larger catchment area, but the elaboration of the structural and control plan of road development has not yet begun. To reduce the heavy impacts on the peripheral zones of Városliget, the planning of roadside green areas should be emphasized.

\section{Natural and dendrological values of the vegetation of Városliget}

Figure 4 illustrates the valuable individuals and clumps of trees. The oldest ones are the 200-year-old plane trees, the largest related stand is located between the Art Gallery and the Rondo. The alleys of plane and lime trees bordering the promenades represent an outstanding value. In addition to the characteristic species, exepcional varieties of 
beech and ash trees, field and Norway maples, poplars, willows, bald cypresses, locusts, cedars, horse chestnuts and catalpas grow in the park (Radó, 1985). Although more the 800 specimen of the original plantation were cut out in the end of the $19^{\text {th }}$ century for the constuctions of the millenium exhibition, the most valuable plane stands still remained. The trees of Városliget form dense stands, and between the closed, forest-like and the loose, bosket-like areas extensive meadows and lawns provide ecological, recreational and aesthetical variety.

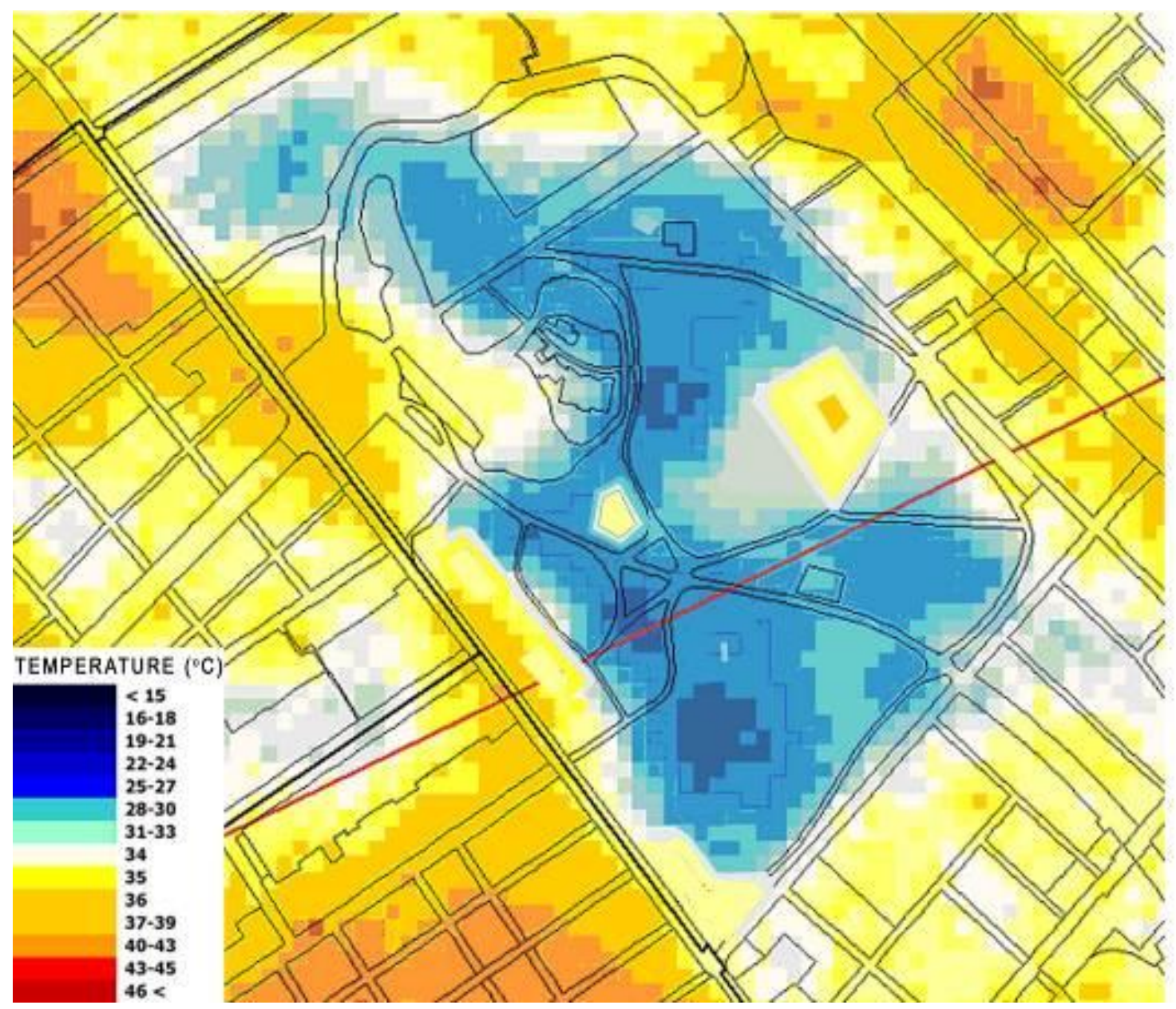

Figure 3. The predicted effect of the planned Museum Quarter on the surface temperatures of Városliget

\section{Analysis of the changes of the vegetation and the ecological sensitivity of Városliget}

In case of old parks and mature stands of trees, the increased sensitivity has to be considered: every artificial intervention modifies the capability of the habitat, the water balance, the local climate or the soil quality on a greater or lesser extent. Vulnerability is extant in many levels and from many points of view. The mature stands grew in conditions fundamentally different to the current urban environment. The changes of the habitat over time have implied a continuous load for the trees, to which they became more or less adapted. For those plane trees which were planted and later adapted to a humid, swampy environment, changes of water balance ( because of civil engineering and underground constructions) is hardly tolerable. The vulnerability is even higher 
today, as the urban climate is much more arid and warmer. The situation is different when a one-off, shock-like event like a large-scale oversized construction is being carried out. For mature trees it's very difficult to adapt to such conditions, if they can adapt at all. And finally, the constant load of recreational traffic in public parks, and mostly the large mass events with their concentrated impact should be interpreted as specific ecological impact, deriving from their function as well.

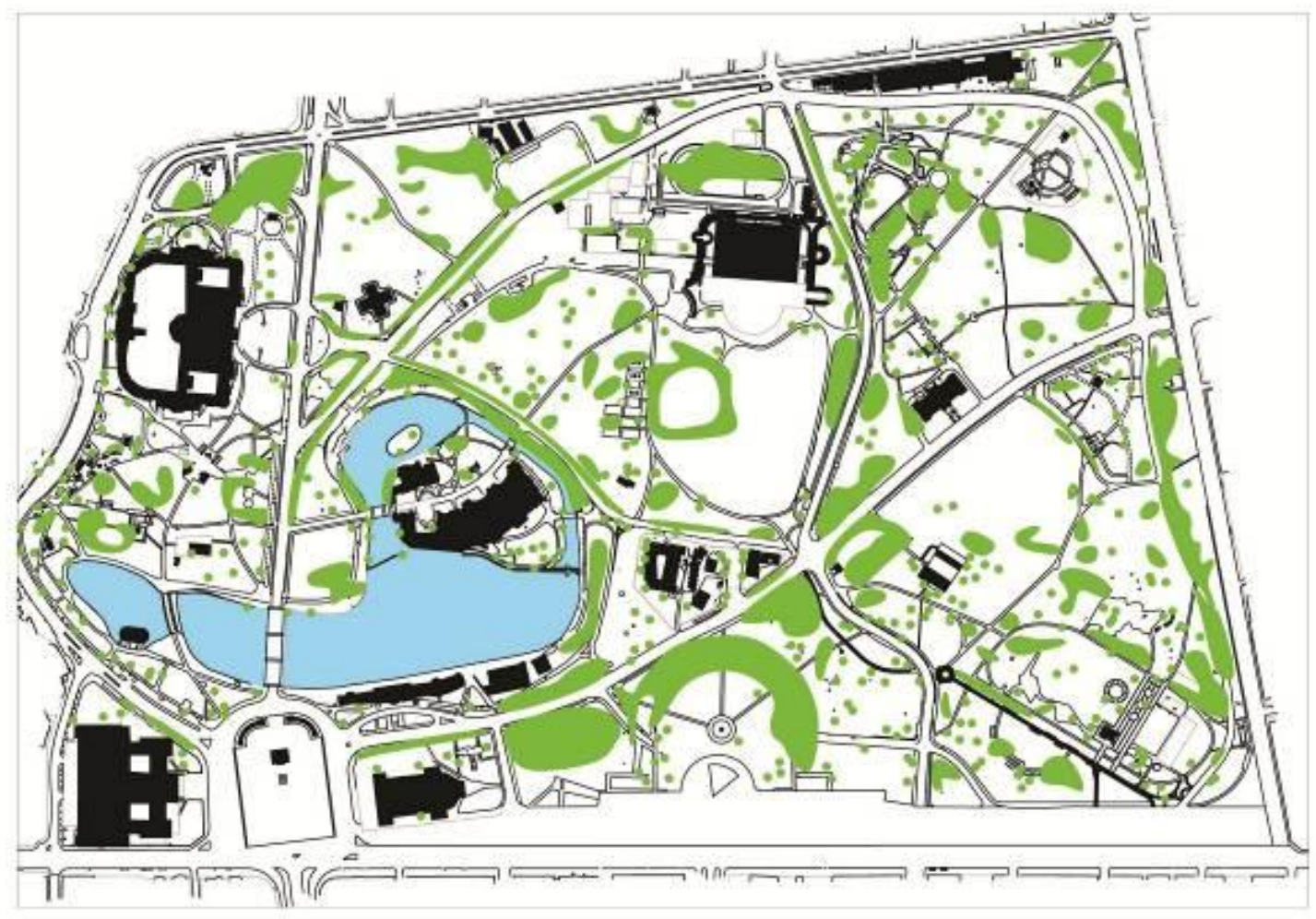

Figure 4. The open space structure of Városliget and the valuable, characteristic clumps of trees - without rating and the survey of the individuals (Based on the Városliget Building Regulations, analysis of the current situation 2014. BFVT Kft. and onsite observations)

In terms of sensitivity, the green areas of Városliget are rather heterogeneous. Primarily, sensitivity depends on the nature of the vegetation, the coverage (canopycovered, shaded areas) and the position in the urban fabric. Largely paved areas or greens covered with resistant vegetation are more tolerant to environmental impacts: Heroes square, areas between Kós Károly promenade and Állatkerti boulevard and sports fields are amongst these zones. The areas covered with mature vegetation, such as the plane boskets of the Rondo, the Art Gallery and Királydomb (The King's Hill) should be classified as sensitive. The open lawn areas (because of treading and the exposure to blazing sun) and the peripherical zones (according to the pollution of high traffic, borders by Ajtósi Dürer sor and Dózsa György út) should be classified as vulnerable. Inside the park the vegetation creates an own microclimate, but this positive effect cannot prevail by the sides of the park as the non-existing line of shrubbery cannot filtrate the impacts of traffic (heat radiation, winter salting). The small botanic garden and the thematic blinds garden are highly sensitive as a variety of plants with special needs and peculiar garden structures were installed there. 
The institutions of Városliget are mostly located in the less sensitive areas: the Zoo, Széchenyi Thermal Bath, the Grand Circus, Gundel restaurant, the Museum of Fine Arts, the Art Gallery, the ice skating rink and the Transport Museum. Though Vajdahunyad Castle is situated in the core area of the park, the main direction of approach leads through a less sensitive part. On the other hand, he acces to facilities by motor vehicles, mostly in the territory of the former BNV (the beer tent and Petoffi Concert Hall) does bring negative environmental impact. Beside these facilities there are several other zones of the park which attract high traffic, and because of their character or structure, the vegetation is unable to tolerate the impacts sufficiently. One of these facilities is an important attraction of the park, the Városliget lake, where the overpopulation of different species of water algae is a grave problem. The main meadow (napozórét, a lawn for sunbathing) gets a shock-like load of visitors during mostly during mass events. The usage of Királydomb (The King's Hill) is a functional problem, it's a vulnerable area: while dog walkers threaten the cleanliness, bikers risk the quality of the grass. The high traffic of Kós Károly promenade is a significant harmful factor, as it devides the two parts of the park, producing significant air contamination. Based on on-site monitoring, the number of visitors is the highest around the institutions and the lake. The peripherical areas - the statue park, the Királydomg and the Rondo - attract less visitiors (Fig. 5).

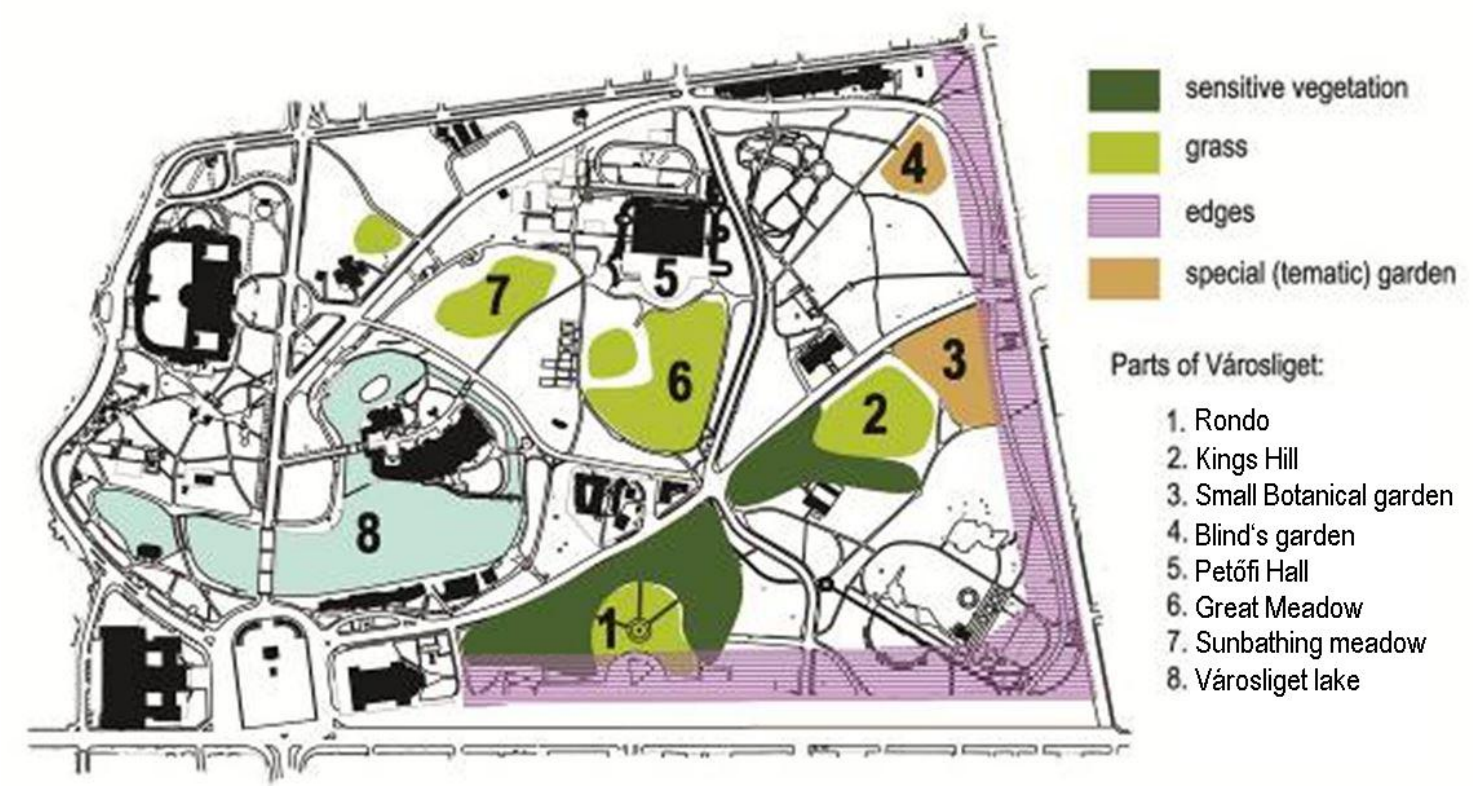

Figure 5. Areas of different rate of sensibility in Városliget

\section{The environmental-ecological impacts affecting Városliget as an urban green}

\section{Changes of land use throughout the 200 years long history of Városliget}

On Nebbien's layout the area of Városliget consisted of 130 hectars. Although the plan had not been totally implemented, the area remained of similar size for decades. First, the margin area was taken away for the construction of the new railway lines, and than in 1866 a further 30,8 hectares were expropriated for the Budapest zoo (24\% of the original territory). The Millenium Exhibition of 1896, noting the fact that it was only a temporary event, extended on a remarkable area of 55 hectars $(54 \%$ of the total 102 
hectars of the park then). Later the Budapest International Fair (BNV) occupied 23 hectars $(22,4 \%)$ for a durative time, reaching its maximum size between 1925-42.

After the Second World War a decesion was made for the widening of Dózsa György út, and at the same time, the establishment of Felvonulási tér in 1951, mostly for military parades and labour movement marches and for a safety spare runway, causing a loss of 4,58 hectars for Városliget. The square was finished in 1952, with a regulatory latitude of 80 meters, and with a fully paved surface partly sacrificing the precious tree stands of the former Rondo. The former Budapest International Fair was managed under the name of Budapest Industrial Fair between 1955 and 1974, occupying a smaller, but closed area. The relocation of the fair started in 1972, but a few pavilions still remained in the expo area. The total reconstruction of the park was set in 1974-75, when the current structure was layed out. Since then no major works have been implemented, and the area of Városliget remained untouched: 98,2 hectars, $76 \%$ of original territory of Nebbien's park.The actual area of the park premises (without the Museum of Fine Arts and Heroe's Square) is 87,7 hectars today. Accordingly, the area of Városliget was decreased by 42,3 hectars, losing $34 \%$ of its initial territory, while the population of Budapest tenfolded.

\section{Changes built up areas in the area of Varrosliget}

In the 1816 first landscape plan of Nebbien only a few smaller follies and buildings were installed, strongly subjected to the service of the park, acquiring a total area of $1320 \mathrm{~m}^{2}$ (Fig. 6).

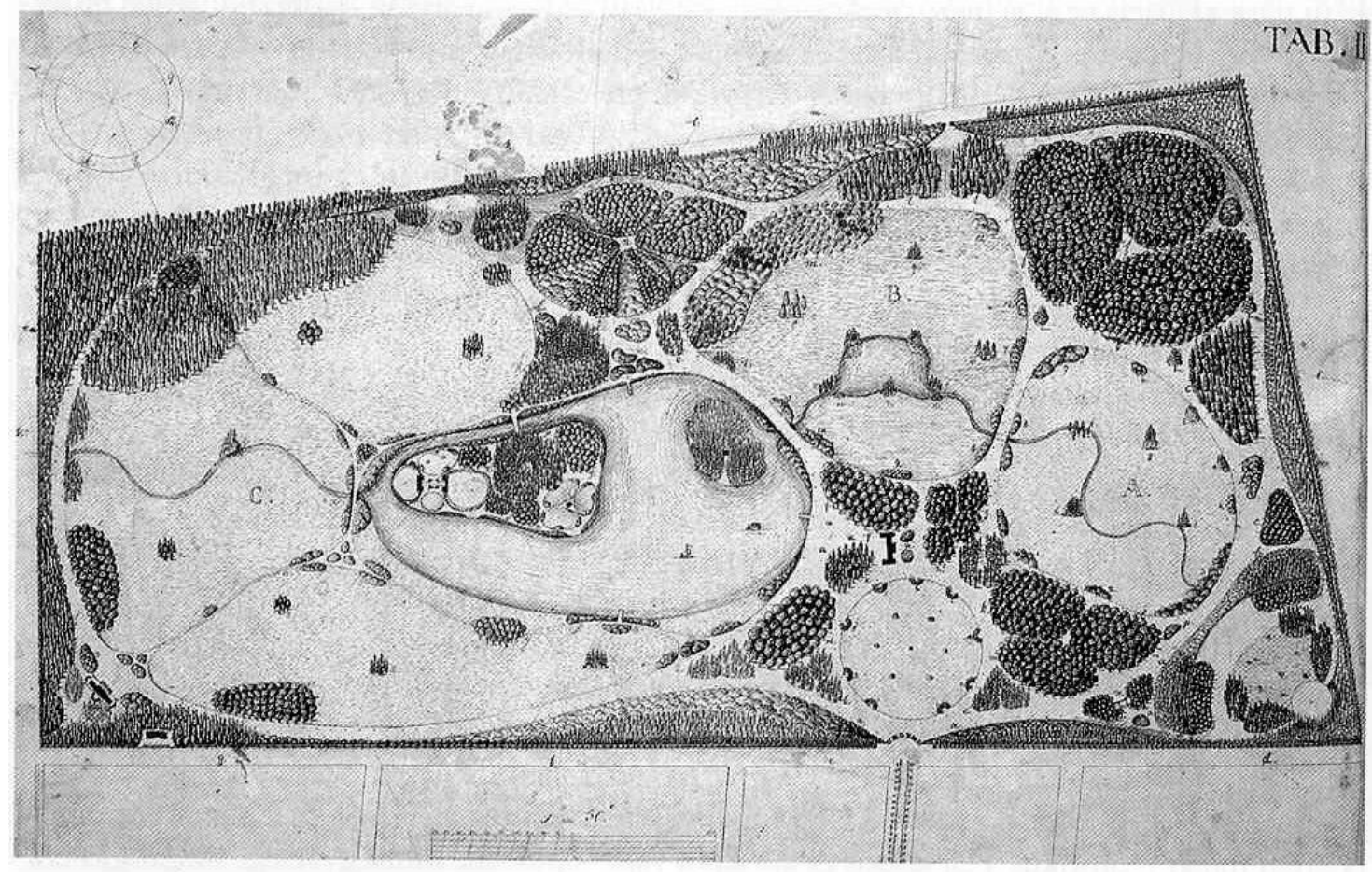

Figure 6. Plan of the Városliget by Heinrich Nebbien, 1813-1816.

(Budapest, Kiscell Museum) 
On the 1836 map $1660 \mathrm{~m}^{2}$ of built-up area can be counted, the edifices are mostly smaller inns and the buildings of the farmstead. In 1850 built-up areas made up 3000 $\mathrm{m}^{2}$. The first large-scale construction was the Millenium Exhibition. The total, intendedly temporary built-up area occupied $104.000 \mathrm{~m}^{2}$ (11\% of the park area then!). $94.731 \mathrm{~m}^{2}$ was established in the premise of the exhibition in the form of 240 greater or lesser halls and pavilions, while $9396 \mathrm{~m}^{2}$ was occupied by edifices outside of the boundaries of the exhibition area.

The idea of keeping a few of the intendedly tempory buildings emerged in connection with Vajdahunyad castle, an emblematic exhibition of the outstanding works of Hungarian arhiectural history. Replacing the temporary building, the new, now permanent complex was finished in 1904 according to the plans of Ignác Alpár. For the Millenium Exhibition Városliget was given a new main portal. The intersection of the park and the recently finished Andrássy út was originally emphasized by a pavilion designed by Miklós Ybl, as the peristyle of the Millenium Memorial and the Museum of Fine Arts was constructed only at the turn of the century. The square was decorated by loose plantations of trees and flowerbeds for three decades, the current, fully paved surface was layed out for the Eucharistic Congress of 1937. Heroes Square with the Museum of Fine Arts and the Art Gallery occupies 4,6 hectars of the effective park area.

Károly Räde's plan to structurize the environment of the pavilions left behind after the Millenium Exhibition was carried out in 1929. According to the trends of garden design of the time, a system of paths meshing through and through the park was installed along with a set of extensive paved leisure areas and foregrounds (Fig. 7).

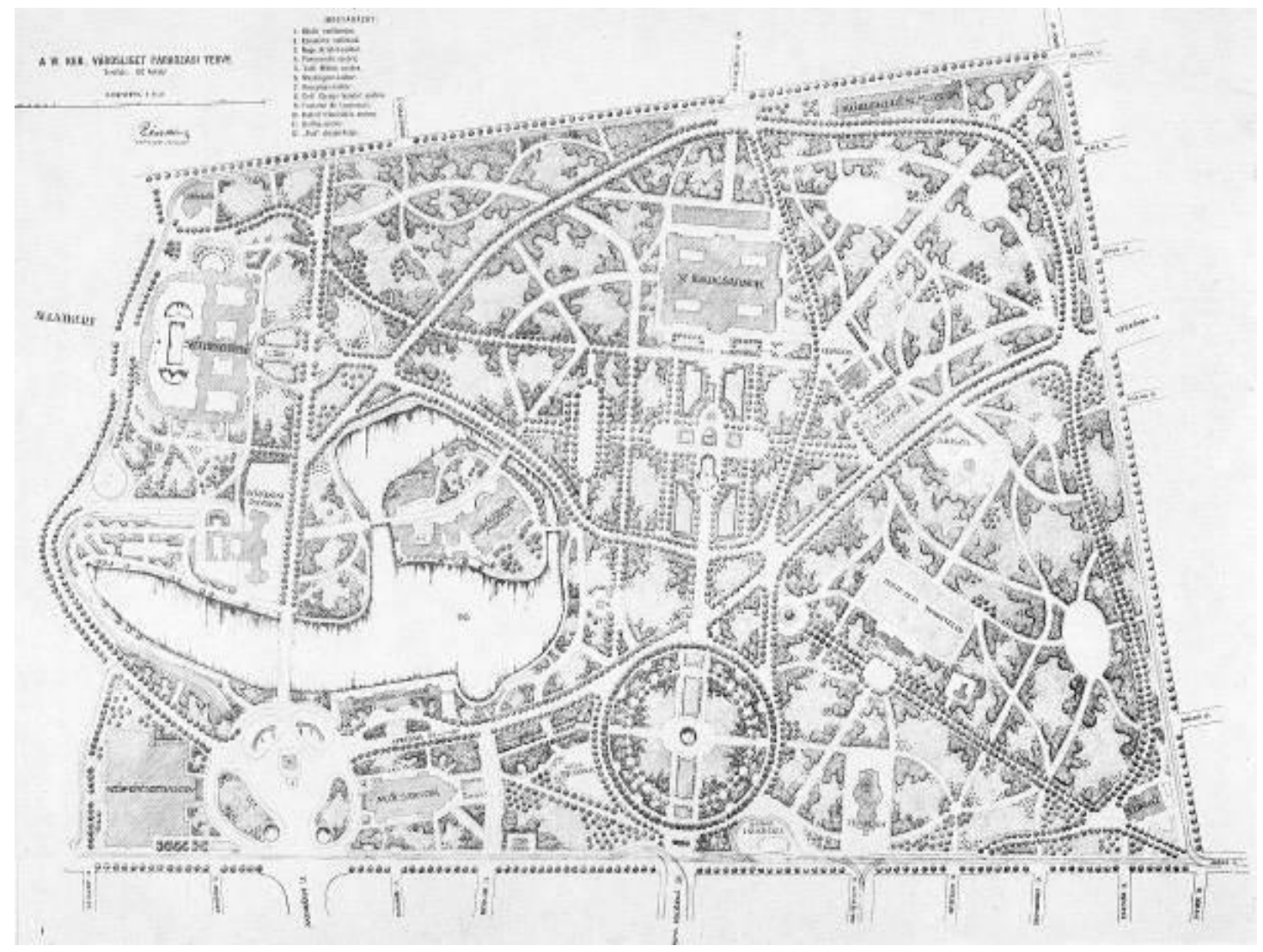

Figure 7. Városliget, Károly Räde's reconstruction plan

(Thaly, T., 1958) 
Several buildings perished or were damaged in the bombings of the Second World War. During the reconstruction works some parts of the vegetation was replanted, and the majority of Räde's road system was renewed. The puffer zone to the city was provided by Dózsa György út and the extensive paved area of Felvonulási tér, as a victim to the political regime. In 1955 the Budapest Industrial Fair was launched for the first time, proposed by the City Council of Budapest. During the first few years most of the buildings were temporary, as the motto of the organizers illustrates: 'The Fair closed by the end of May, and grass grew in the beginning of July, even on the place of the nicest pavilions.' (BIV, 1960) The era of fairs characterized by temporary constructions lasted until 1963. The development of the fair required further sacrifices from the park: the premise of the fair reached $140.000 \mathrm{~m}^{2}$ in 1957 and $260.000 \mathrm{~m}^{2}$ in 1960 (with a built up area of 20.918 in 1957 and 52.174 in 1960). The area of the the territory occupied by the edifices and pavilions doubled in only three years (Final report, 1960), this fact shows how the Budapest International Fair caused further damages in the stands and vegetation of the park.

After the reconstruction works of 1974-75 $72.158 \mathrm{~m}^{2}$ of built-up area was left in the park $(7,3 \%$ of the total park area, including Heroes square and the Museum of Fine Arts). Since than no major changes have been carried out, the decrease of functions and a process of general decline characterized Városliget in the past 40 years. This fact stands for the edifices, too. Several buildings have lost their function, some of them have been demolished, and the ones still standing are in the condition of rapid deterioriation. The current built-up area is $56.072 \mathrm{~m}^{2}, 5,7 \%$ of the green area (including Heroes square and the Museum of Fine Arts), which is nearly twice the size of the $3 \%$ maximum proportion (according to the OÉSZ regulations). The new Városliget Construction Regulation allows a maximum of $7 \%$ of built-up area, preparing for the installation of the new Museum Quarter.

\section{Changes of water surfaces in the park}

On the plan of Nebbien a lake of 10 hectars can be seen (together with the two further smaller ponds and meandering creeks the open water surface occupies 11-11,5 hectars), which didn't change until the completion of the Millenium Underground in 1896. The channel bordering the once-was Páva island was buried during the construction, and the current land mass was formed. The underground runs in the former lake bed, dividing it into two parts. The water level of the fragment closer to the zoo is higher, during winter only this part is filled with water. The current water surface is 6,2 hectars (half of the original extension).

From late autumn until spring, the 4-5 months operation of the ice rink drastically disarranges the appearance and the ecological system of the lake. The area of the ice rink is 3,4 hectars (55\% of the total surface). Only the lakebed near the zoo is filled with water, occupying a total surface of $6000 \mathrm{~m}^{2}$, which is less than $10 \%$ of the summer values. The remaining 2,2 hectars are empty during this period, visitors can take pleasure of the vision of the bare concrete lakebed. Visitors seeking the sight of water are clustered in a relatively small area, and this crowded land use is not worthy of the history of Városliget, one of the busiest public parks in Budapest. The absolute and relative descrease of water surfaces is also problematic from an ecological point of view, as the park cannot fulfill its conditioning role as a city green, and its functions as a habitat and air cooling island are compromised. The periodic absence of water surface 
has a stressful effect on the parks ecosystem, and on mostly the mature stands surrounding the lakebed.

The imprints of park usage on the grass vegetation of Városliget

Városliget is one of the most intensely and continuously used public parks of Budapest, and it's easy to observe in the condition of the grass surfaces. Thanks to the regular mowing and the occasional irrigation, the lawn areas form a coherent surface and are capable of the satisfaction of recreational needs. However, if the surfaces are examined closely, it's clearly visible that amongst the purposely sown species in a greater or lesser proportion, but native perennial weeds are present too. It can be considered a natural process, but the proportion of weeds is too large in Városliget.

The intensively used grass surfaces - in addition to the usual annual maintenance require a complete renewal every 10 years, according to soil compaction and the resulting loss of soil metabolism. In Városliget these renewals were respectively cancelled, and the demanding grass species cannot bare such conditions. The lawns are presumably affected by the lack of irrigation as well (a yearly $200-250 \mathrm{~mm}$ of irrigation is required during the vegetation period). The rich and green spots of grass around water runoffs (caused by the failure of the irrigation system) justify this assumption.

As most of the grass species is light demanding, in shaded and semi-shaded spots lawn will grow thinner even without intensive use. The lawn cannot recover as the thin substances cannot ensure the appropriate local climate. Downcast faults and $30-50 \mathrm{~cm}$ of unevenness caused by excessive tread and overload can strongly influence the water balance of the soil, which is already shown in the vegetation. In populations growing on higher ground, drought-tolerant species are present in much greater numbers. The presence of Trifolium repens and other Trifolum species is not a major concern, and Taraxacum or Bellis can still be considered natural, but mass occuring (sometimes exclusive) sand couch (Agropyron junceum) and common knotgrass (Polygonum aviculare) populations show that not even the minimum living condition of grass species is given.

The low quality of grass vegetation is not only an aesthetical or functional concern, but it worsens the ecological performance of the total green area. The thin, frayed surface can not be sufficiently involved in the reduction of the heat-island phenomenon, and the poor assimilation and vaporization capacity has a negative effect on the park as a whole (Fig. 8).

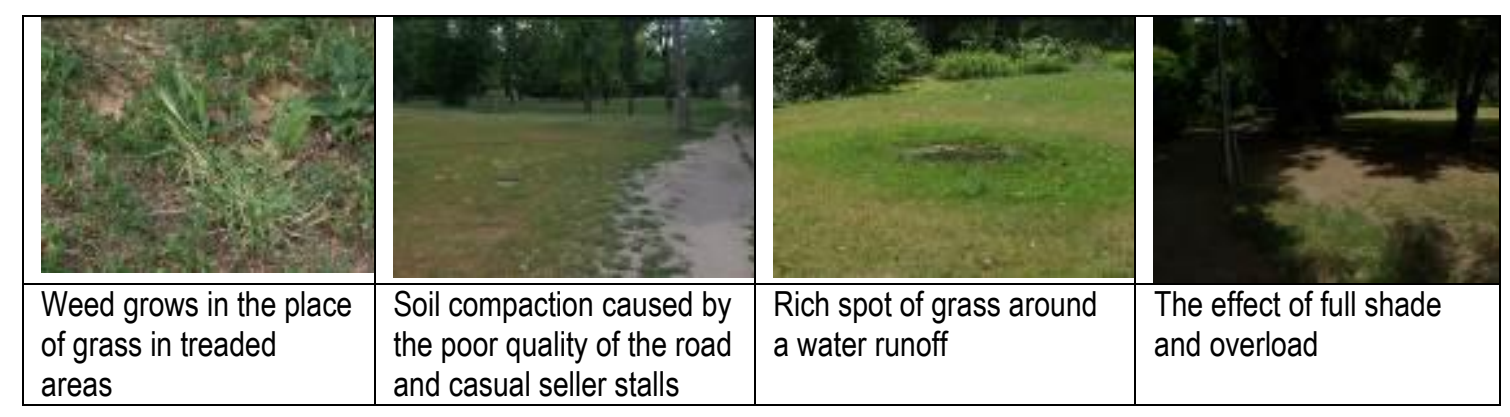

Figure 8. Condition of grass vegetation in the Városliget in June 2014 (photo by Gerzson, L.) 


\section{Social - recreational effects and loads}

\section{Everyday use as a recreational park}

We have little knowledge on the environment/ecological load of park uses of the early peroid, the only reference point to the potentional users is the population of the city. During the period of the planning of the park (1813) the total population of Pest, Buda and Óbuda was 70.213, from which Pest had 36.153 inhabitants. In the first half of the 19th century, until the opening of the Chain bridge in 1849, most of the visitors were from Pest. Lacking other recreational areas, presumably thousands of inhabitants of Pest visited the park during the weekends and festival days. The intended use of the park is known from the description of Nebbien: 'The park was intented to serve people of all classes, so they can meet the comfort of mother nature' (Nebbien, 1816). Unlike the concept of Nebbien, Városliget has never become a public park in the original, romatic meaning of the word. The park was mostly visited by the urban aristocratic classes and the bourgeoisie. In the beginning of the $19^{\text {th }}$ century the main functions of public parks and gardens included recreational walks (alone or with family and friends), carriage joyrides and horseback riding, or in a broader sense, all kinds of social activities (Bugár-Mészáros, 2008). Amongst quiet retreats, meditation and contemplation in an environment providing an aesthetic, idillyc experience, scenic views and refreshment, the parks gave place to practicing physical activities, thermal and spring water bathing and milk cures. In addition to its important role as a promenade and esplanade, the parks of that era served as garden halls for cabarets as well. From the 1830s spring festivals appeared in Városliget, the Whit Monday celebrations and May Day festivities attracted large crowds.

The population of Pest-Buda sevenfolded during the Millenium Exhibition (506.384 people). Large numbers of people started to visit Városliget from the $1860 \mathrm{~s}$, still not regularly, but for famous side-shows and other major events (Radó, 1986). The omnibus route started to operate in 1862 and the zoo opened in 1866, followed by several entertainment facilities established in the detached areas (the Grand Circus, restaurants, side-shows, amusement park). The bathing culture was initiated by the establishment of a spa resort. Herewith a wide zone of institutional, service and entertainment facilities were created in the northern side of Városliget, which clearly pushed the park usage toward a year-round balanced distribution of attendance. A more complete and general park usage was generated by the popularity of ice-skating. The ice of the Varosliget lake was initially used by families of the bourgeoisie during the winter months, but from the 1870 s this new way of diversion and sport became generally widespread - insomuch that a new skating hall was designed before the end of the century according to the plans of Ödön Lechner, and later of Imre Francsek.

In 1920 the population of the capital exceeded one million. The popularity of Városliget could continue to grow, as Rädes rehabilitation plan proposed an intensively used public park divided by a system of pathways, promenades, and spacious leisure areas. The park was given its multifunctional areas satisfying the needs of all ages of users (leisure gardens, playgrounds, sports and playing fields, lakeside piers and deck benches) during the 1974 reconstruction, when the population of Budapest reached 2 million (Bakay, 2013). Regarding the rich and diverse plantings, the ornamental value of the vegetation increased. So did the time available for recreation during labour days and weekends: massive park use became an everyday phenomenon. The usage of parks 
as plages during the summer months appeared during this period of time. These factors together brought a robust, regular and steady load to the green surface of Városliget.

Since the rehabilitaion works of the 1970s a loss of functional supplies can be observed. The sports and playfields created for the youth became ran down, most of the fields and playgrounds (for example the playground for preschoolers next to the Rondo) were demolished. These areas are nowadays shelter for the homeless, or popular places amongst dog walkers.

Surveys of park usage were carried out in October 2013 and May 2014, in connection with the new Museum Quarter (Szilágyi et al., 2013). According to the observations the daily number of visitors in autumn is estimated around 7.600 on weekdays and 14.000 on weekends, while on a summer day it's more than two times more: 20.800 on weekdays and 25.500 on weekends. Based on the surveys, the catchment area covers almost the whole VI. and VII. districts and the central area of the XIV. district, including 122.000 inhabitants. Most of the visitors are residents to one of the districts mentioned above.

The traffic data revealed that the impact on the different subfields of Városliget is different. Most of the visitors (549 people/hour on a Saturday afternoon) appeared around Vajdahunyad Castle, while around peripherical territories lacking attractions such as the Statue Garden, the Beer Tent and the Rondo, the traffic load is a lot lower. The visitor traffic of the individual subfields is shown by the index-number of use intensity (number of visitors in the subfield valued in $\mathrm{m}^{2} /$ person, Table 1). According to the survey the areas of the Statue Garden and Kings Hill (Királydomb) are the least crowded (1000 $\mathrm{m}^{2} /$ person), while the frequented subfields (Vajdahunyad Castle and the Városligeti Lake) are the most crowded $\left(90 \mathrm{~m}^{2} /\right.$ person). Regarding the total area, the average use intensity on a summer day in Városliget is $377 \mathrm{~m}^{2} /$ person.

Table 1. Intensity of recreation on various parts of Városliget (Szilágyi et al, 2013)

\begin{tabular}{c|c}
\hline Area & Use intensity $\left(\mathbf{m}^{2} /\right.$ person $)$ \\
\hline Vajdahunyad Castle & 87 \\
Városligeti lake & 88 \\
Heroes sqaure & 215 \\
Széchenyi bath & 273 \\
Petőfi Hall and the sports fields & 393 \\
Playgrounds & 426 \\
Beer tent and its surroundings & 464 \\
Higway track playground & 503 \\
Great meadow & 587 \\
Rondo & 602 \\
Statue garden and Blind's garden & 985 \\
Kings Hill & 1668 \\
\hline
\end{tabular}

Based on the results of former researches, we assume that under the intensity of 200 $\mathrm{m}^{2}$ /person the visitors start to feel cluttered (Nagy, 1997; Szilágyi et al., 2013). During the on-site survey $78 \%$ of the respondents answered no, $22 \%$ answered partly or wholly yes to the question if they felt crowded in the park. The congestion feeling is typically subjective, and cannot be considered constant for an individual either. The nature of recreation (active-passive), the age, the physical and/or mental weariness all play a significant role in deciding if the recreational traffic of almost the same kind is acceptable or disturbing. The large fluctuation in the average park use intensity (166 - 
$1054 \mathrm{~m}^{2} /$ person) is natural and neccessary at the same time, as a public park should satisfy a large variety of recreational needs.

The observational studies in park usage clearly show that the rate of passive recreation is remarkably high. Former researches verify that this is a typical trend: the rate of active activities is continuously decreasing in the park, and are mostly concentrated to areas where suitable facilities are available. Such subfields are located in the peripheral zones, so the different activities are separated interestingly along an internal partition line. This can be observed in the case of such active activities which doesn't require supporting facilities: joggers and bikers are using the peripheral areas as well.

\section{Mass events - shock-like recreational impacts}

The first mass events held in Városliget were the National Fair and the Millenium Exhibition in 1885-86. Those were followed by the Budapest International Fair (192542) and the Budapest Industrial Fair (1955-74). Although these were temporary ocassions, the territory of the fairs remained enclosed for the rest of the year, and the separated islands were not suitable for traditional park uses, which resulted in a significantly smaller green area available for regular rectreational users.

The regular, shorter or longer events attracting large crowds became frequent from the first half of the $19^{\text {th }}$ century. The mass events of the socialist era in the second half of the 20th century, the May Day celebrations, military and labour parades lack accurate data of attendance: it's suspected that the number of visitors reported in the press was exaggerated by the pressure of the socialist propaganda. The organized mass events have a onefold, shock like impact on the green surfaces, and the density and regional concentration of these loads cause permanent degradation of the habitats.

To establish a potential relief plan for Városliget, a study plan was carried out at the end of the 1990s (Szilágyi and Nagy, 1999). In 1998 and 1999 most of the events organised in Budapest took place in Városliget. In 199819 occupancy permits were issued by the municipality of Budapest, mostly for cultural, political (1998 was a year of parlaimental elections), sanitary and sports events, music festivals and fireworks. Seven of them were mass events of several days (for example an equestrian event on the Kings Hill). In 1999 six longer term mass events were held in Városliget, causing vast impact on the ecosystem (Szilágyi and Nagy, 1999).

The three main categories of events based on their ecological impact are the following:

1. Long-term mass event with huge impact, in a highly or moderately sensitive area

2. Short-term mass event or moderate event, in a moderately or weakly sensitive area

3. Short-term event or smaller event, in a moderately or weakly sensitive area

The programs of the $1^{\text {st }}$ category cause strong and concentrated tread damage, soil compaction, noise, soil and air pollution mostly because of the transport vehicles, often even during the preparatory phase.

During the retesting of 2014, the events of 2013 were studied, along with the May Day celebrations of 2014 as a case study. In 2013 a total number of 49 programs $(2,5$ times more than the reported events of 1998-99 - without the political meetings which do not require notification) were held, 8 of these events lasted for more than one day. Most of the events were limited to a specific area, but in 10 cases more sites were included, causing a diffuse type of load. Based on he distribution of the events 
according to load type and the estimated attendance, about 3 million individuals visited the reported programs and mass events (Table 2) - without the political meetings, of which there are no official data available, as they don't require official notification.

Table 2. Calculation of number of visitors at the organised open air programs in Városliget in 2013.

\begin{tabular}{c|c|c}
\hline Category & Number in 2013 & $\begin{array}{c}\text { Estimated attendance (based on the estimate of } \\
\text { organizers and the programme) }\end{array}$ \\
\hline 1 & 5 & 400.000 person/event (long term events included) \\
2 & 17 & 50.000 person/event \\
3 & 24 & 5.000 person/event \\
\hline
\end{tabular}

On $1^{\text {st }}$ May 2014 a survey was carried in the frame of the Városliget research about the May Day festivities using as a case study. This occassion is the traditional meeting of the left-wing parties and labour unions, covering the whole territory of the park and attended by several thousands of visitors. The land use is intensive, diffuse with typically concentrated loads (amusement park, funfair, stages, etc.). The edifices requiring transportation by heavy vehicles were respecively placed on lawn covered areas. By the following day the litter was cleared away, but the tread damage and soil compaction was clearly visible. Concentrated downcast faults caused by heavy vehicles and edifices resulted to be the most significant and lasting. There were no remaining compaction faults in the place of the stages and bars.

\section{Personal narratives about the Városliget}

Every citizen has long associations about some parts of the city, which are impregnated with many memories and its meanings. By evoking our memories, we attach stories to each part of the settlement, therefore we vest places with significance (Lynch, 1960). Due to people's common memory we are able to speak about places, which communication forms the place identity (Dúll, 2009). In the 1970's, researches made by Harold Proshansky presumed that the evolution of personal identity - what is rooted in our memories - not only depends on the certain person or the encircling people, but it links to objects, particular places and spaces (Proshansky, 1978). The online visitor survey - made by the Corvinus University, Faculty of Landscape Architecture in 2014 - included three questions focusing on park users's personal narratives. People were asked to tell about their first, their pleasant and their unpleasant memories connected to the Városliget.

It can be concluded that the first memories of the respondents linked primarily to the passive recreation (Fig. 9). These activities are related to walking, relaxing, nature observation or visiting an event or program in the park. The answers often emphasized the importance of the natural environment, the experience of nature: "I was at the age of six, when I first visited the Park. There were playgrounds around the Museum of Transportation. But the most memorable for me was the chilling under the 50 pieces of horse chestnut trees in summertime". Lake Városliget and the surrounding environment - included the animals - appeared in the answers significantly as well: "I spent a lot of time in my childhood boating in the Lake Városliget and with the study of newt, which were living in the lake in that time." Underpinning the importance of having nature experience in cities, remarkable number of park users mentioned the visit of Budapest 
Zoo as a first memory, which is the north-western border of the Liget (Fig. 10). Memories linking to active recreation were shown significantly lower percentage. They are rather connected to learning or doing certain sport activities, especially ice-skating and cycling. The playgrounds of the Városliget (Kings' Hill, Playground and the Playground of Transportation) were also considerably mentioned in the answers, particularly in the current 19-40 year old generation's reply. This result may have some connection with the park renovation made between 1974 and 1978, when many new and high-quality playgrounds were built. In some cases respondents described surprisingly concrete memory images, even connected to certain objects, such as "As a child, the great wooden castle meant incredibly exciting world for me" or "I enjoyed the most one of the playgrounds wooden wall, which has been demolished since then."

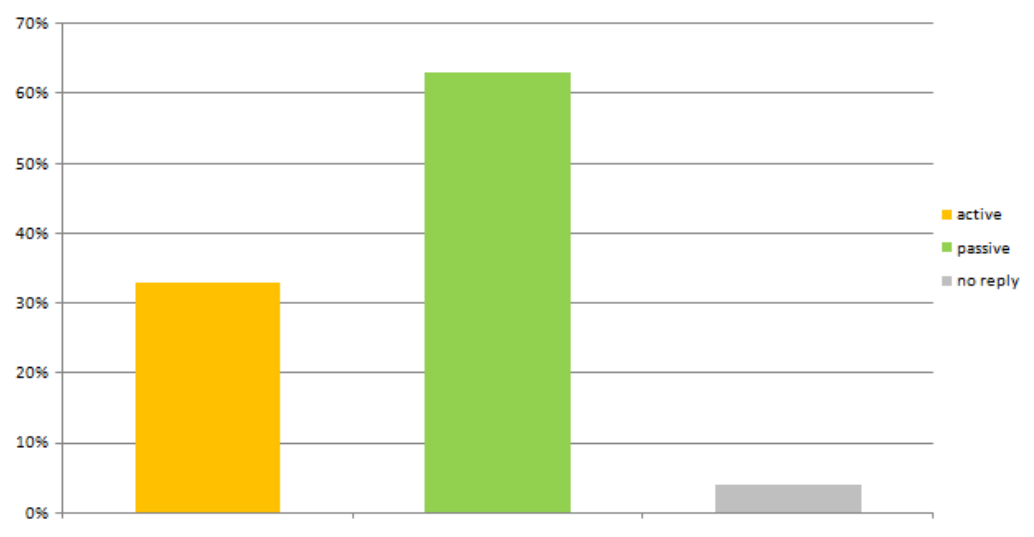

Figure 9. The distribution of activities connected to first memories

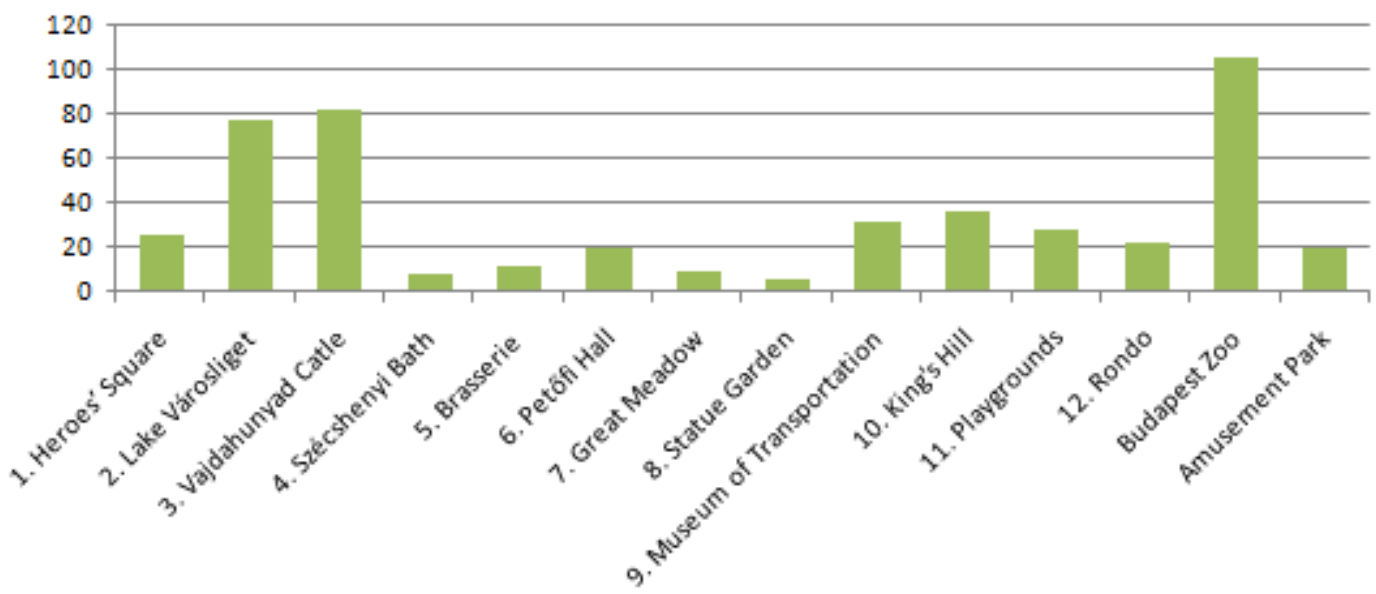

Figure 10. The presence of the delineated areas in the responses

The answers about the pleasant memories show similarities with the first memories. We can conclude that the first impression gained from an area plays a significant role in a subsequent representation of a place, that is to say, what kind of meaning do we attach to a site. Based on the responses, the positive associations connected to open-air social activities, such as walking and meeting with family and friends. 
The unpleasant, negative memories typically can be sorted in four groups. The responses related to maintenance, safety, traffic and to those group of people who are detached from the society. Concerning to the area, typically the Ötvenhatosok tere, the Rondo and the Petoffi Hall and its setting are the most unpleasant sites. In addition to „dereliction and negligence" the crowd and congestion are the most described negative memories: „Sometimes it is impossible to escape from the noise (traffic, loads of people)." The responses also confirm that the Városliget is not intended for mass events, above $200 \mathrm{~m}^{2} /$ per visitor the feeling of crowd can evolved. If more people staying in a particular area, the possibility of nature experience stops (Nagy, 1997).

About the Városliget, fifteen percent of the respondents did not express their negative memories. Nevertheless, the illustrative answer is: "Actually, I do not have unpleasant memories, but I did not like, if the Városliget was too noisy or full of garbage. Or If I could not sit on the bench because there were only few or they were in poor condition. It bothers me, when there is no irrigation on summer and I miss the old fountain."

The respondents reflected to the historical background of the Városliget as well. For instance as a first memory the Heroes Square appears with the meaning of ,pride and amazement”. The „design of the Stalin-square” interpreted as an unpleasant and „The fall of the Statue" as a pleasant memory. Based on the survey the most questionable political content - event is the 'Festive May Day' ( $1^{\text {st }}$ May). According to people's memories it is sometimes „charming and unforgettable”, sometimes „overcrowded and chaotic" program.

Through the history of the Városliget many layers - sometimes incompatible with its original function - has been added, which left a mark in the physical and ecological characteristics of the park. Getting to know about the background of this area, perhaps it is not surprising that ideas are turning up time-to-time which are overlook the original purpose of the Liget. According to the park users' image the most divisive points - such as Ötvenhatosok tere, Petőfi Hall and its environment - are those ones, which had many turnovers in its meaning. At the same time, positive answers tied to those congruent places that carry and support the function of an urban public park.

Today the Városliget faces with new challenges. The Városliget Building Regulation has completed, giving space for the new Museum Quarter, which will give a subsequent meaning to the Park without a doubt. By the change of the built-in rate, not only the urban green or the biological active surfaces will reduce, but probably the quality and the quantity of the stimuli will change in the park. With the realization of this mega investment the citizens recreational and relaxation places can decrease.

\section{Conclusion}

Public parks have been serving the citizens for hundreds of years. Beyond the initial sanitary, social, welfare and educational functions, modern city greens satisfy a huge variety of recreational needs. The diverse, well-used city parks providing the sensation and freedom of nature are the pledge of liveability from both social and urban ecological point of view. The extensive (sometimes hundreds of hectares large) parks are effectively conditioning and improving the urban environment, depending on the quality, the condition and the vitality of the green surface, and on the efficiency of maintenance, nursing and protection of the area.

The case study prepared for the sample area of Városliget revealed most of the ecological pressure deriving from park usage, the operation of the city, environment 
pollution and territorial needs of urban development. Urban climate and the heat-island effect are serious threats to city greens, especially if the dense green area is disrupted by inactive surfaces (buildings or paved areas). The above mentioned environmental and ecologic problems need a strong urban policy committed for sustainable and liveable urban environment. The building of green aspects into urban policies is a key element in this program which means the keeping and increasing of urban green spaces, the protection of urban biodiversity and ecosystem (Csete and Horváth, 2012).

The primary role of public parks is the satisfaction of everyday, regular recreational needs. Beyond quality maintenance, a regenerative refurbishment is needed every 10-15 years, to maintain the proper level of recreational and conditional effects. Through the example of Városliget is clearly visible that the open air mass events cause large-scale overloads to parks. Since there are events held nearly every weekend, the sensitive areas have no time for regeneration. The programs announced for the same time and same place are perfect in terms of organization as they reinforce each other, but at the same time are disadvantageous for the park as they cause massive overload instead of load sharing. The primary problem is not the existence of such mass events, but the presence edifices, buildings and land users not necessarily inherent to an open air occasion, and mostly the heavy transport vehicles which are not using the designated road network. With competent, coordinated organization and the restriction of the issuance of permits, the further damages done to the green surfaces could be minimised.

The maintenance of the vegetation is of very poor quality, any way not in accordance with the parks importance in urban history and garden art, nor with urban recreational needs, the rate of use or with the overload of urban environment. The park lacks regular renewing maintenance, soil improvement, and regular irrigation, replacement of grass surfaces in shaded areas, just to mention the gravest maintenance and treatment failures from an ecological point of view. Without quality maintenance the park can fulfil neither its recreational nor its urban ecological conditioning functions.

The 200 years of history of Városliget vividly illustrates the gravest threats to public parks: the cities endless demand for construction land and the continuous need for more intensive land use inevitably leads to the sacriface of long term values on the altar of short-term benefits. In favor of the improvement of urban life quality and the liveability of the city, inhabitants still need parks to provide the experience of nature, they enjoy the peace and calmness provided by the valuable, mature tree stands and the historical space structure. A more intensive park use and the installation of edifices have the most harmful impact on the sensitive, protected area preferred by nature lovers. The monstrous buildings and extensive paved areas appearing in the border of the park extend the heat island effect and other urban mischiefs towards the core areas.

Városliget was the first city park in the world designed through an international tender and assigned by the city, implemented in an urban area by the promotion of the citizens. It should deserve the status of a listed historical park regarding its cultural and historical importance, artistic values of landscape arhitecture and hundreds of years old vegetation. This legal status could ensure the protection, appreciation and national, or even international fame of the park. Both Margitsziget and Népliget are protected as historical parks, but the 200 years old Városliget still isn't. This lack of protection contributes to the fact that today the park is treated like a construction area for the Museum Quarter. The recreational functions, the land use and the densely built-up neigborhoods strike the ecosystem enough already. 
Budapest commited a serious offense against Városliget for two reasons. First, when after the then modern and up-to-date reconstructions of 1974 the municipality let the park to run down and become funcionally obsolate. The functional supply of the park didn't follow the changes of social habits, in the past 40 years there was only withdrawal but no progress. The second serious omission was to fail the opportunity to declare Városliget a historic park, protected by monumental conservation. (The Grosser Garten of Dresden was declared to be a historical park just after the act of monumental conservation came into force in the GDR in 1975 (Krihning, 2013)).

The biggest fault of the concept of the Museum Quarter (planned to be constructed in Városliget) is the degradence of the park as a value itself, the subordination of the worlds first public park, which has been satisfying the recreational and environmental needs of the citizens for 200 years, to the interests of tourism. The management plan of Városliget should be developed together with the timely rehabilitation plan, including the replacement of tree stands based on an ecological risk assessment and the modernization of the parks recreational suppliesconsidering the open space structure of the park. In contrast, the Városliget project doesn't include the impact assessment of the environmental overloads created by the preparation and the implementation of the constructions; there is no recommendation for the compensation and balance of these harmful processes. During the multi-year period of the implementation, a socialrecreational deficit must be expected as the park as a construction area will be useless for everyday visitors (7000-24000 person/day depending on the season and labourweekend days). Budapest should provide some kind of compensation, at least temporarily. Knowing the weak, undersized green system and faulty green network of Budapest, the surrounding brown field transport areas should be developed urgently both from a recreational and urban ecological point of view.

\section{REFERENCES}

[1] Bakay, E. (2012): The role of housing estates' green surfaces in forming the city climate of Budapest. - Applied Ecology and Environmental Research 10(1): 1-16.

[2] Bakay, E. (2013): Retroterek, retroparkok. Kert- és szabadtérépítészet Magyarországon 1950-1990. (Retrosquares, retroparks. Landscape Architecture in Hungary 1950-1990.) Terc, Budapest. 85.

[3] Bugár-Mészáros, K. (2008): A két pesti körönd története. (The history of the two circus of Pest). - Örökség, Budapest 10: 5.

[4] Chadwick, G. F. (1966): The park and the town. Public landscape in the 19th and 20th century. - F.A. Praeger, New York.

[5] Choi, H.-A., Lee, W.-K., Byun W.-H.. (2012): Determining the Effect of Green Spaces on Urban Heat Distribution Using Satellite Imagery. - Asian Journal of Atmospheric Environment 6-2: 127-135.

[6] Csepely-Knorr, L. (2011): Early modern landscape architecture, The evolution of public park theory until the end of 1930s. - Corvinus University of Budapest, Faculty of Landscape Architecture. Doctoral dissertation.

[7] Csete, M., Horváth, L. (2012): Sustainability and green development in urban policies and strategies. - Applied Ecology and Environmental Research 10(2): 188.

[8] Dúll, A.: (2009): A környezetpszichológia alapkérdései - Helyek tárgyak, viselkedés. (Basic issues of environmental psychology - Places, objects, behavior) - Budapest, L'Hartmattan, 213-235.

[9] Gábor, P., Jombach S. (2008): A zöldfelület intenzitás és a városi hősziget jelenségének összefüggései Budapesten. (The relation between the intensity of green space and the 
urban heat island phenomenon in Budapest.) Falu, Város, Régió 1. Városi zöldfelületek, 31-36.

[10] Gábor, P., Jombach, S. (2009): The relation between the biological activity and the land surface temperature in Budapest. - Applied Ecology and Environmental Research 7(3): 246-247.

[11] Joardar, Souro D., (1989): Use and Image of Neighborhood Parks: A Case of Limited Resources. - Environment and Behavior 21(6): 734-762.

[12] Krihning, S. (2013): Grosser Garten in Dresden - a court garden transformed into a public park. 4D - Journal of Landscape Architecture and Garden Design 2013(31): 4-20.

[13] Lynch, K. (1960): The image of the city. - MIT Press, Cambridge Massachusetts

[14] Nagy, K. (1997): Közparkok és közkertek használata (The use of public parks and publc gardens) - KÉE KTT, Budapest. Kandidátusi Értekezés (Doctoral dissertation)

[15] Nebbien, H. (1981): Ungarns Folksgarten der Königlichen Frey-Stadt Pesth (1816) Herausgegeben und bearbetet von Dorothee Nehring; Veröffentlichungen des FinnischUngarischen Seminars an der Universität München, München, 1981. S.XV. § 5.

[16] Oláh, A. B. (2012): The possibilities of decreasing the urban heat island. - Applied Ecology and Environmental Research 2:173-184.

[17] Proshansky, H. M. (1978): The city and the self-identity. - Environment and Behavior 10:147-169.

[18] Radó, D. (1985): Budapesti parkok és terek. (Parks and squares in Budapest). - Magyar Nemzeti Galéria, Budapest, 23-35.

[19] Siklóssy, L. (1931): Hogyan épült Budapest? (How has Budapest been built?) (18701930) - Fővárosi Közmunkák Tanácsa, Budapest. 1931, Reprint Állami Könyvterjesztő Váll, Budapest. 1985.

[20] Schams, F. (1821): Vollständige Beschreibung der königlichen Freystadt in Ungern.- In: Siklóssy, L. (1931): Hogyan épült Budapest? , Fővárosi Közmunkák Tanácsa, Budapest, 30.-31.

[21] Szilágyi, K. (2006): Szabad tér - Szabad piac; Tömegrendezvények a főváros parkjaiban. (Free spaces - Free Market; Mass events in the parks of the capital city.) -Tájépítészet, 1.

[22] Szilágyi, K., Veréb, M. (2014): The City Park's 200 years - Changes in spatial structure and park use in the life on an urban park. 4D - Journal of Landscape Architecture and Garden Design 2014(31): 20-45.

[23] Thaly, T. (1958): A 200 éves Városliget (The 200 years old Városliget). - Gondolat, Budapest.

[24] Toorn, M. van den. (2014): The future of urban parks in Europe; The role of landscape architecture in design and research. 1. Design of parks and urban landscape. 4D - Journal of Landscape Architecture and Garden design 2014 (33): 2-19.

\section{Other Resources}

2013. évi CCXLII. Törvény a Városliget megújításáról és fejlesztéséről (Law of the renewal and development of the Városliget)

1960. évi Budapesti Ipari Vásár Zárójelentése (Budapest Industrial Fair Final Report), Egyetemi Nyomda, Budapest

Capital Research (2007): Városliget, Margitsziget, Népliget Research Report.

Final report of the 1960. Budapest industrial fair, University Press, Budapest

Liget Budapest Competition Programme, 2014.

Szilágyi, K., Balogh P., Fekete A., Kanczlerné Veréb M., Almási B. (2013) Parkhasználati vizsgálatok. Tanulmány 2013. (Visiting Research Report 2013)

Szilágyi, K., Nagy, K. (1999): A fövárosi közparkok terhelhetősége - rendezvények a parkokban. Tanulmány. (The load of capital public parks - events in parks. Study.)

Városligeti Építési Szabályzat, Helyzetfeltáró és helyzetelemző munkarész, Budapest, 2014. (Városliget Building Regulations, Analysis of the current situation, 2014. BFVT Kft. 